DPM

28,5

616

\section{PHOTO ESSAY The endless hurricane: documenting life in the shelters, after Maria hit Dominica}

\section{Why a photo essay?}

Photography has always been an important tool for social scientists. Today, the picture's value as a data, communication tool and art is more relevant that ever: social media, digital photography and cell phones allow for almost anybody to document their environments. However, the limited use of photography essays in research and academia reminds us of the need to diversify our view about the field work and disaster studies.

In the field and for this purpose, the act of taking pictures is not about mastering a technique, it is about the interaction with the people. It requires participant observation and consensus and freedom of the people to choose what they want to share. This interaction is the most valuable part of a photo essay because it gives "a voice" to the people, transforming the photographer into an intermediary to communicate a certain part of their reality. In other hand, pictures can speak by them self, leaving the viewer the option to connect and interpret connect and interpret with the images.

\section{The worst disaster in history of Dominica}

In September 2017 Category 5 Hurricane Maria struck Dominica before pursue its trajectory to Puerto Rico (Pasch et al., 2019). The small island (population 74,000) in the eastern Caribbean between Guadeloupe and Martinique was sweep out for the first time by a Category 5 hurricane since records began (Masters, 2017). The devastation in Dominica was massive, with around 90 percent of houses roofs damaged or destroyed (ReliefWeb, 2017). Also, crops and infrastructure were destroyed, leaving communities isolated due the landslides that blocked roads. For almost a year, around 50 percent of the habitants lived without electricity, according with testimonies of affected people. Eclipsed by the media coverage in Puerto Rico and often confused with the Dominican Republic, the Commonwealth of Dominica its recovering slowly. Almost two years after this extreme hydro-meteorological event, the impact remains noticeable by the number of destroyed houses along the island. Less visible is life in shelters, generally improvised schools without basic services as toilets and in some of them, running water and electricity. For those who do not have the resources to rebuild their homes, to live in shelters is the only choice: the impact in their health and capacity to recovery is jeopardized. For them, the hurricane Maria still is happening now.

\section{Approach}

In February, 2019 in collaboration with the Office of Disaster Management of Dominica, we did a fieldwork to document with local agencies, stakeholders, local leaders, and the affected people, testimonies and interpretations of their actions to cope and survive during the emergency and the following months. Our idea was to identify some of the spontaneous actions that people developed in their communities after the hurricanes that could be taken as baseline for formal preparedness for disaster risk programs, based in the

The author would like to thank Alumni TIES for travel support, Juan Arriata (Student Research Development Center, Puerto Rico) and Donaldson Frederick (Office of Disaster Management, Dominica) for fieldwork support. 
notion of Zero Order Responders (Briones et al., 2018), that reflect people's creativity for deal with immediate needs through social cohesion and resourcefulness. However, in this case, the affected people are still facing the disaster consequences. When people remains in shelters they not fully recovery, they actually are becoming permanent affected: their chances to remain in poverty are high, feeding the social vulnerability circle. The people in the shelters don't have a house to stay, for them the recovery "window" is getting closed; instead looking for coping mechanisms for recovery, they are dealing with an increase of their poverty conditions.

The purpose of this essay is simply to document and communicate through a visual tool the post disaster context of a specific affected population. Despite the limitations of this exercise, we believe it could trigger a stimulant way to document disaster risk impacts in many other places (Plates 1-10).

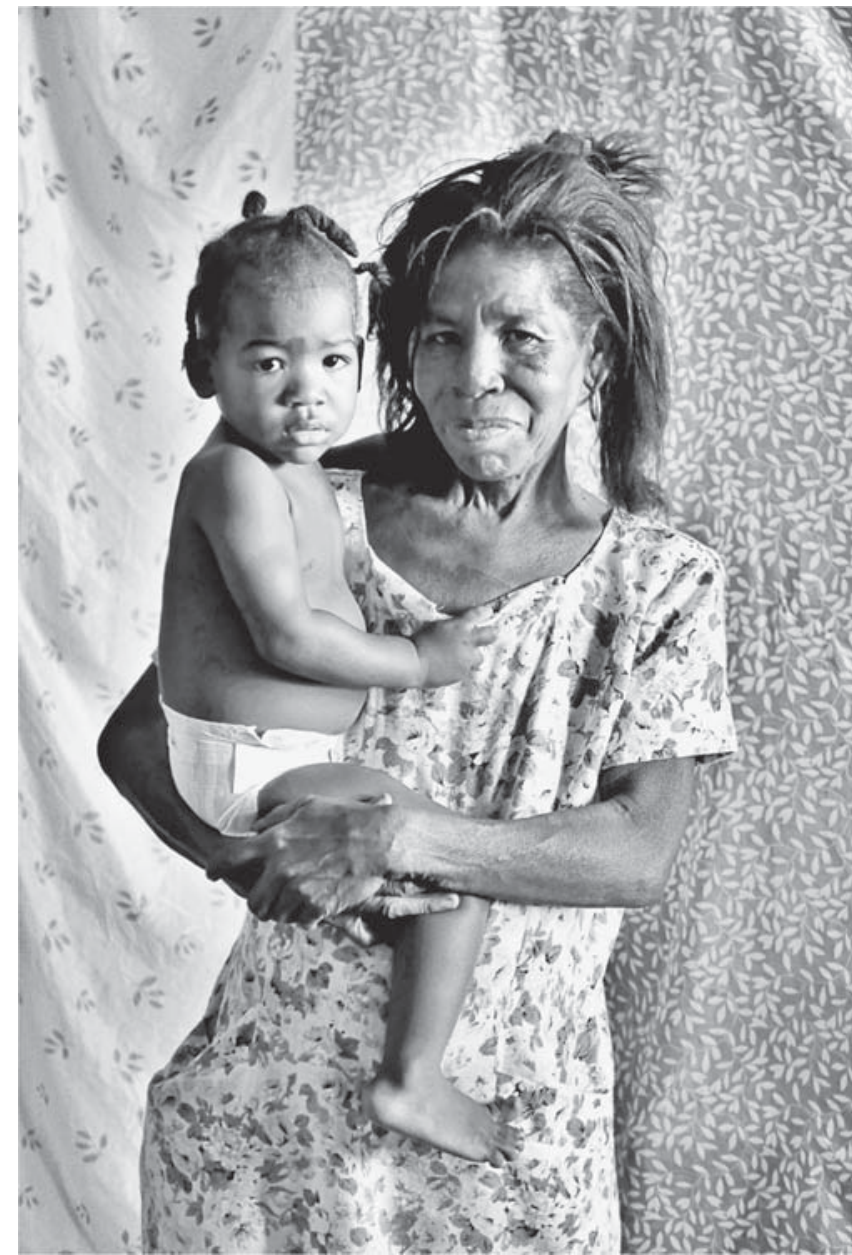

Note: Mother works in tourism industry, still in recovery Source: Scotts Head, Dominica
The endless hurricane
Plate 1.

Born just weeks after Hurricane Maria, this boy grows up in shelter with grandmother, in the picture 


\section{DPM \\ 28,5}

618

Plate 2.

A large number of homes remain in ruins along the island

Plate 3.

This 60-years old women lives in shelter with her husband and other families in

Castle Bruce,

Dominica

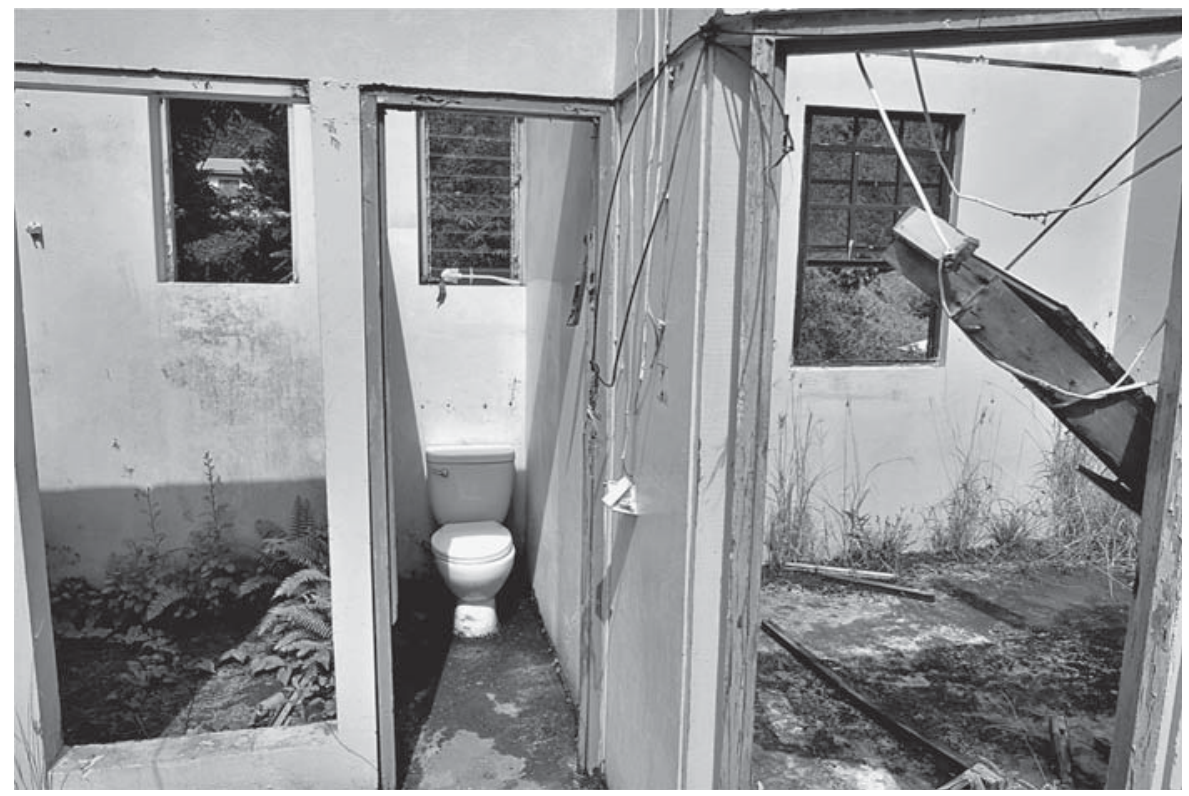

Source: Petite Soufriere Dominica

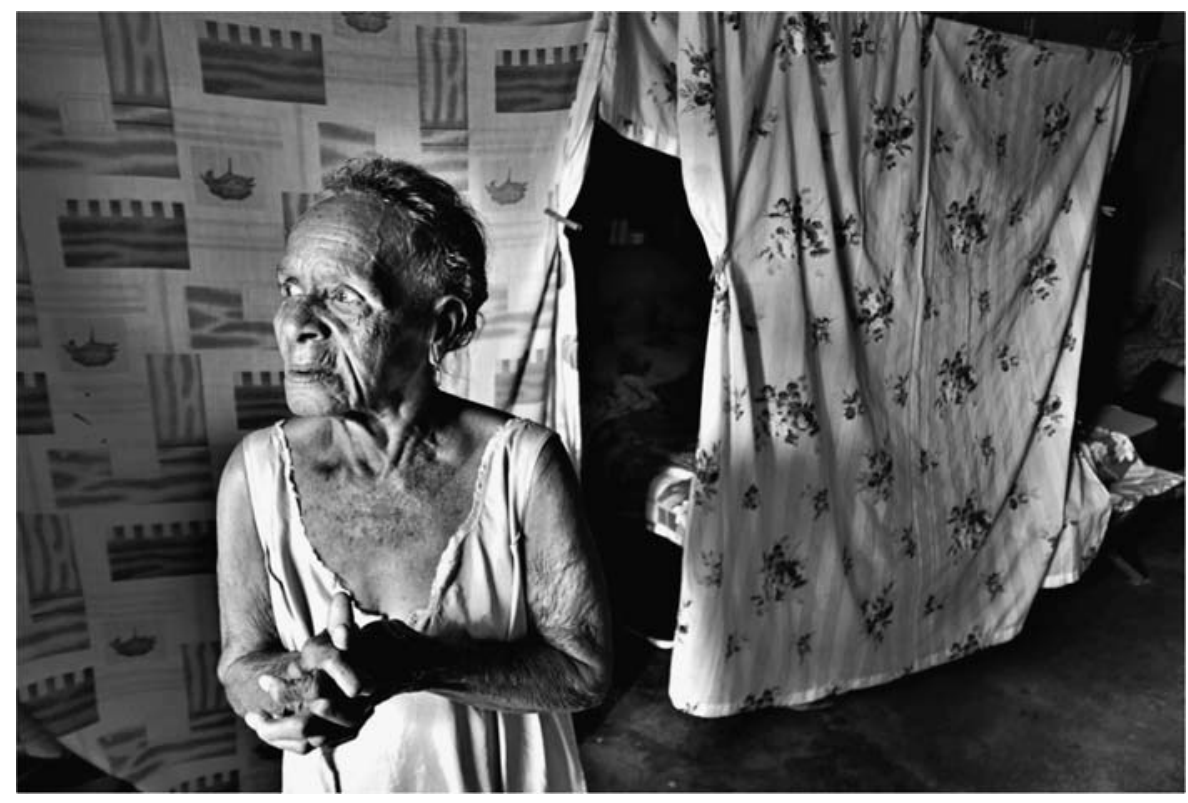




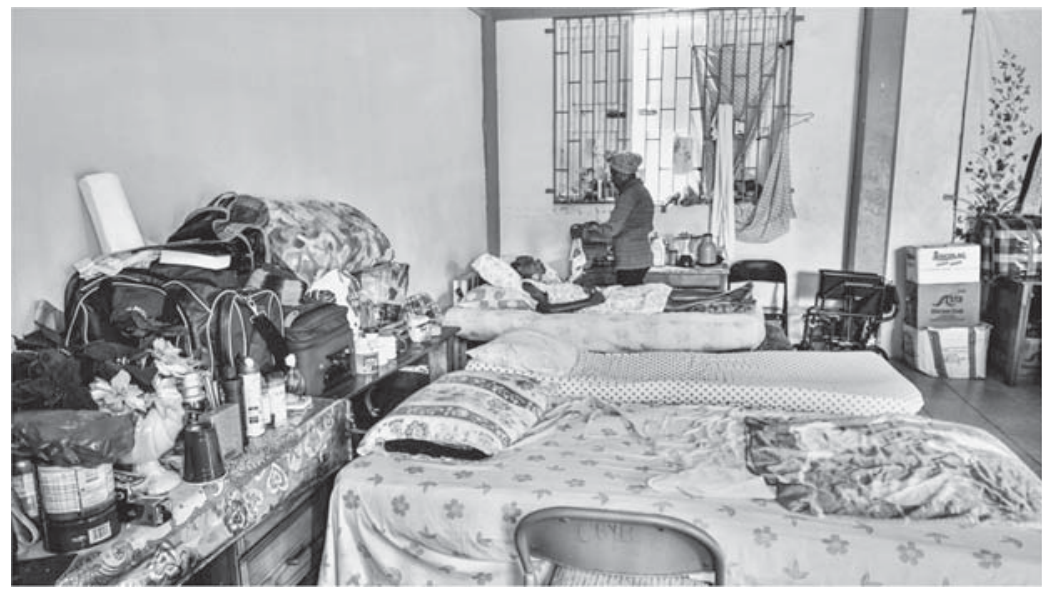

Source: Castle Bruce, Dominica
The endless hurricane

\section{9}

Plate 4.

A woman gets attention from a social worker, who also lives in the shelter

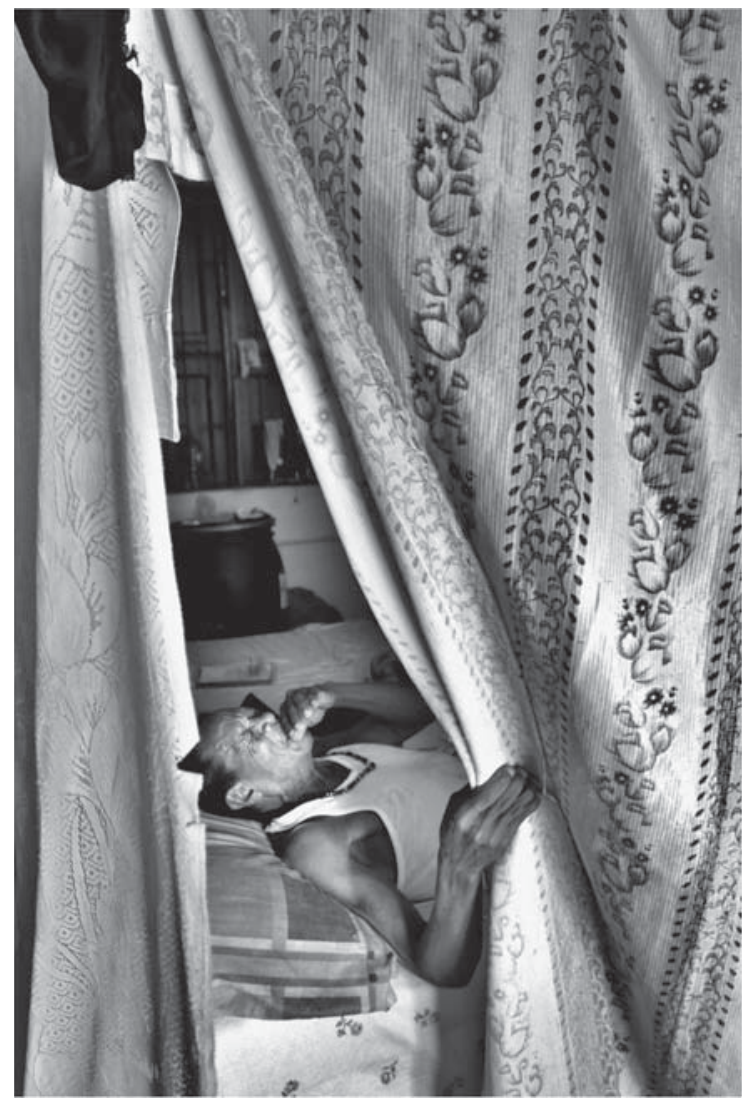

Plate 5.

A man in bed opens his curtain and makes himself visible to the photographer 


\section{DPM \\ 28,5}

620

Plate 6.

With a leg hurt, this man waits to heal and get back to work

Plate 7.

In a recovering economy job are rare and precarious, according to this 18 years old girl in relatively more equipped shelter in the capital, Roseau, Dominica

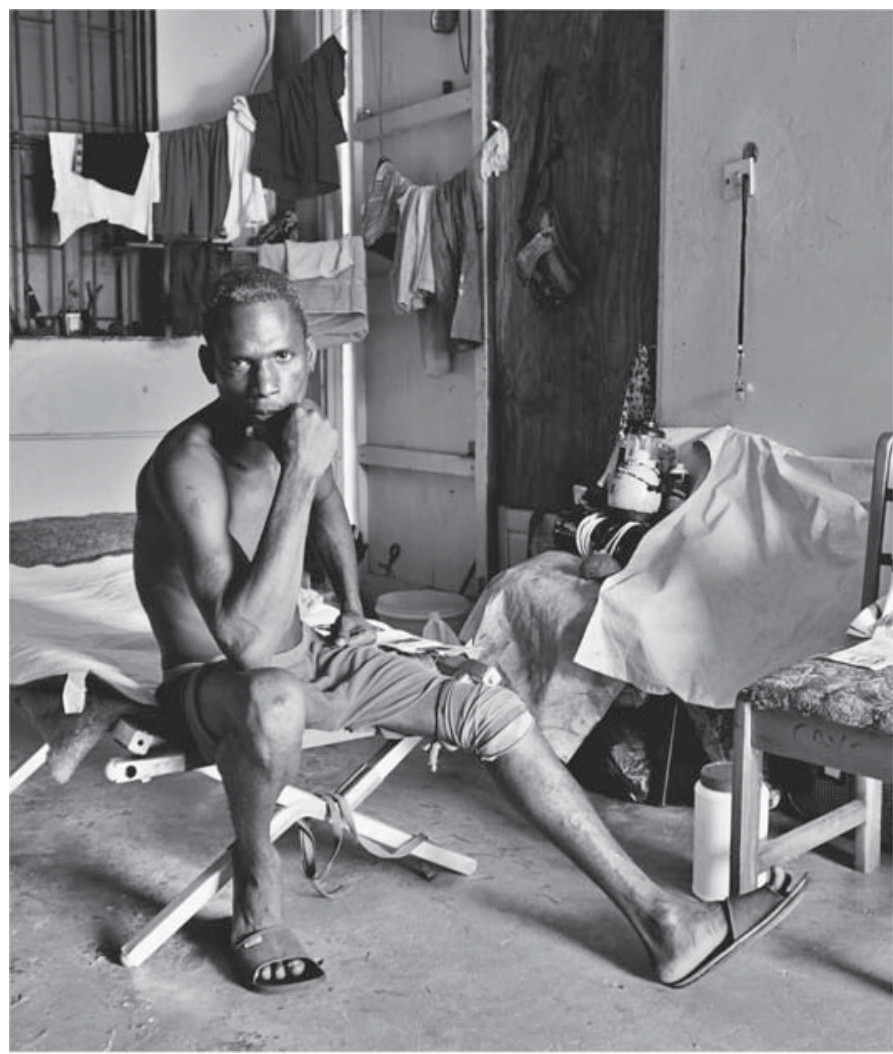

Source: Castle Bruce, Dominica

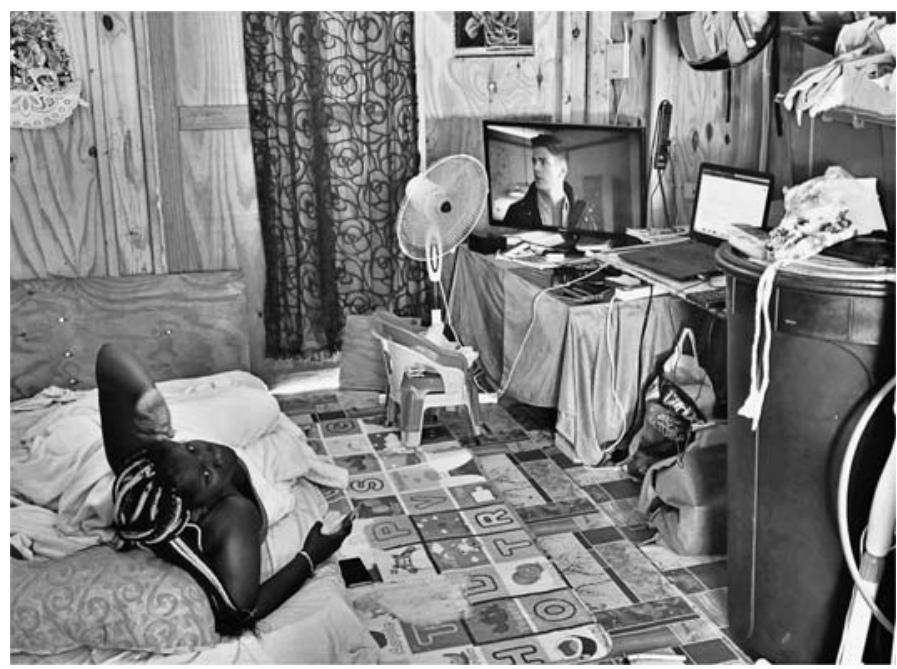




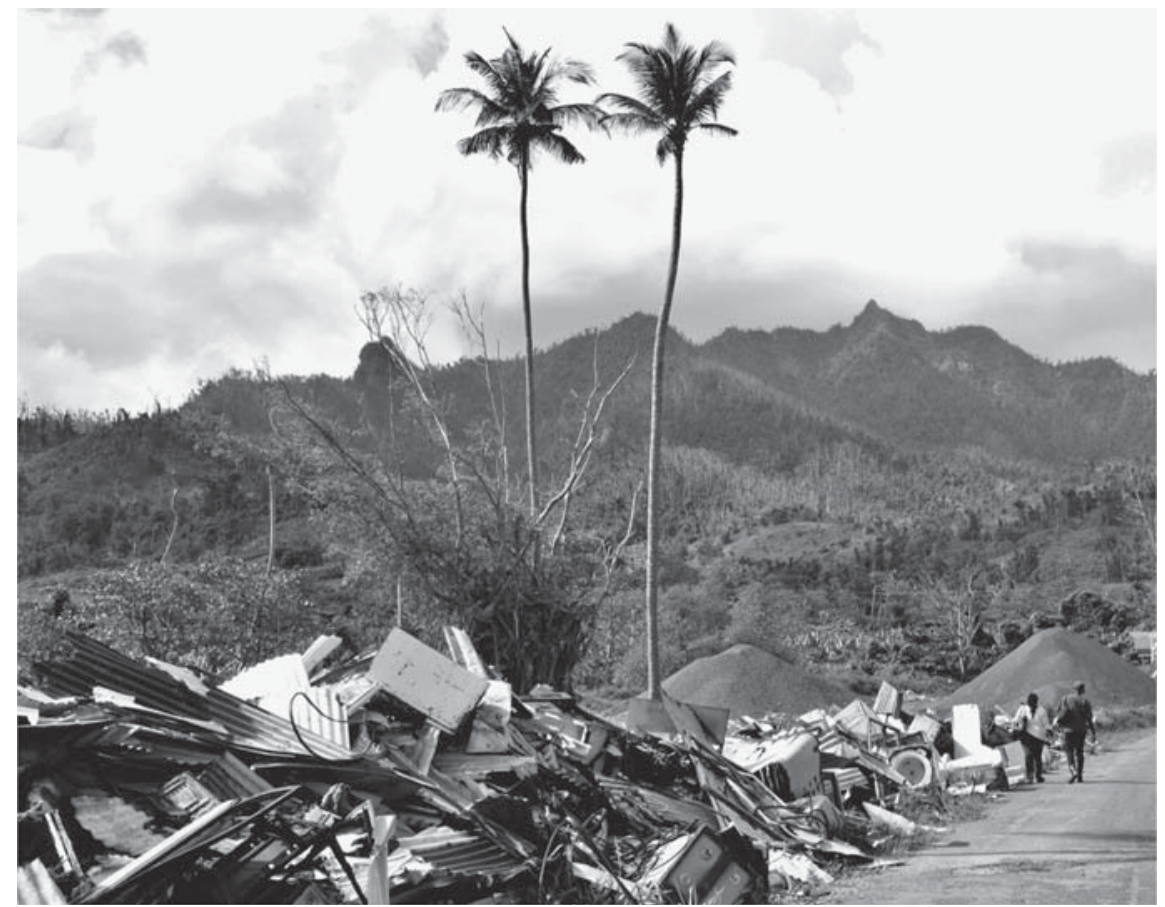

Source: Castle Bruce, Dominica
The endless hurricane

621

Plate 8.

A year and half after Hurricane Maria, the only challenge is not just to rebuild, but also to clean up the debris

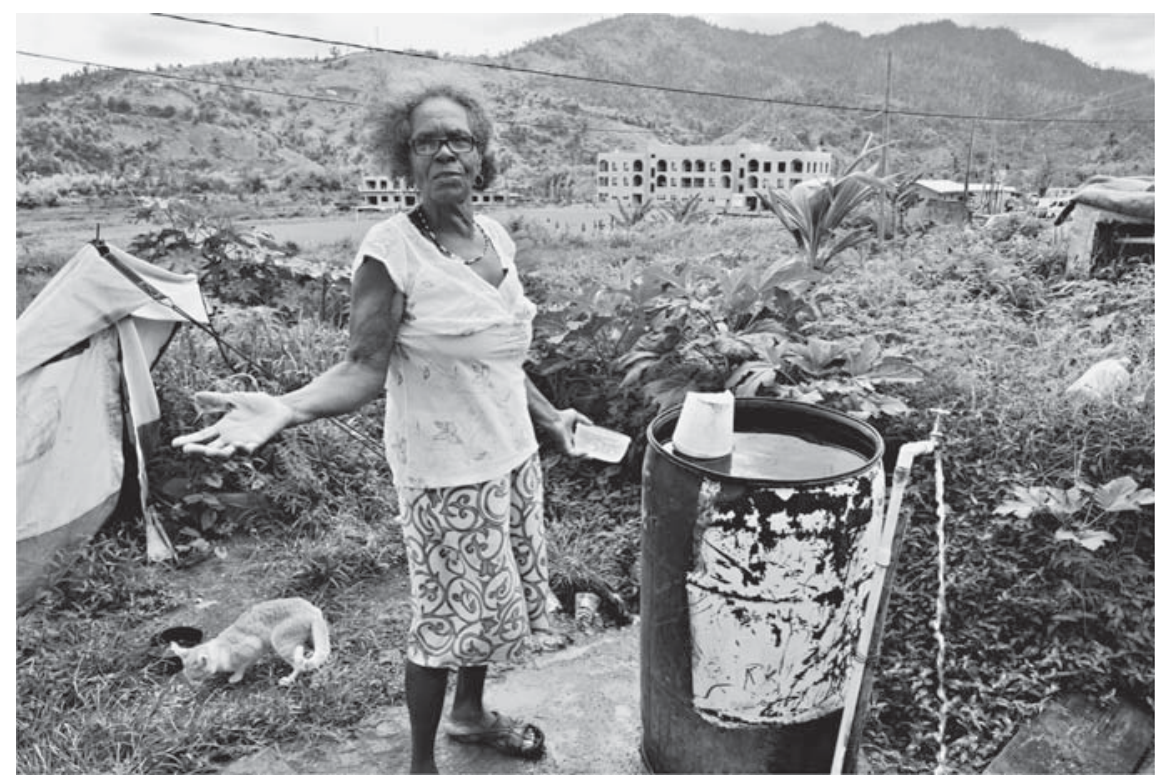

Source: Castle Bruce, Dominica
Plate 9.

This woman waits to be resettled in the houses (at the background) build by contractors with governmental and international funds 
DPM

28,5

622

Plate 10.

A woman takes a break after work by taking care of a neighbor's son, Roseau, Dominica

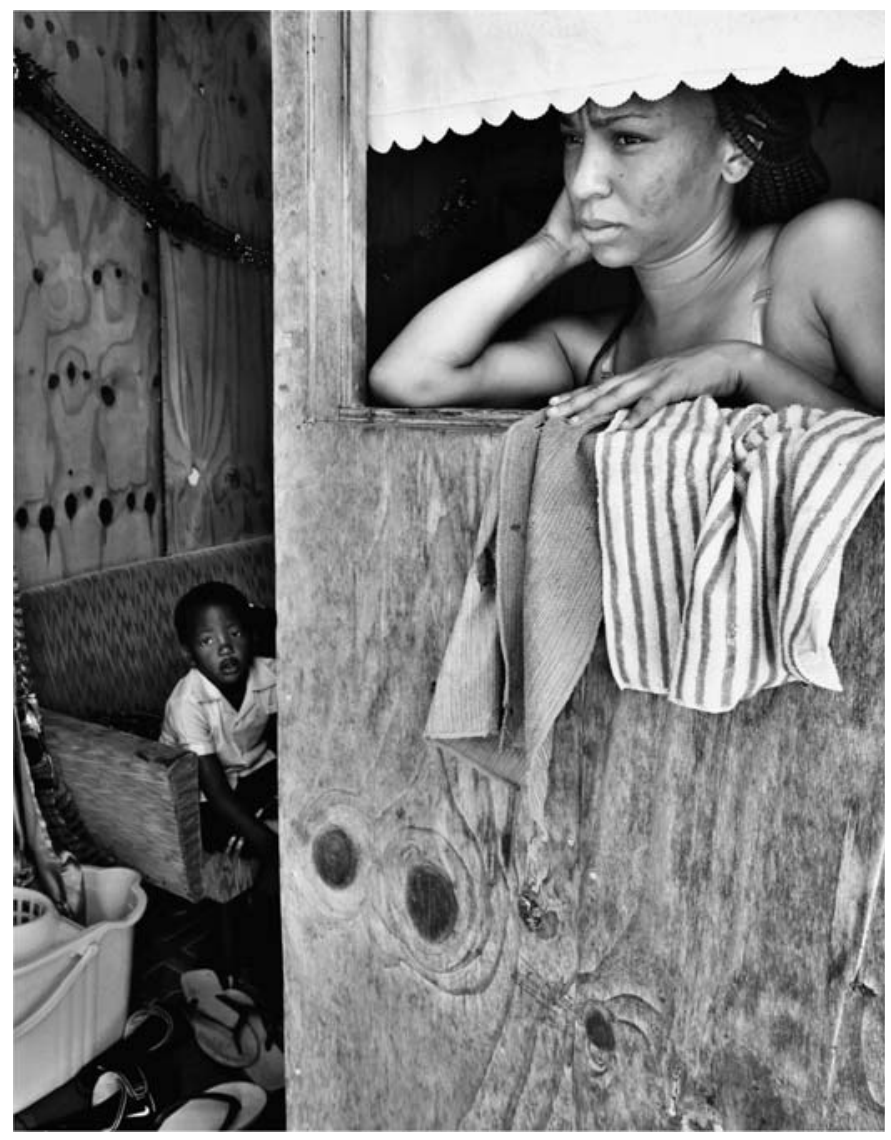

Fernando Briones CSTPR-CIRES, University of Colorado-Boulder, Boulder, Colorado, USA

\section{References}

Briones, F., Vachon, R. and Glantz, M. (2018), "Local responses to disasters: recent lessons from zeroorder responders", Disaster Prevention and Management: An International Journal, Vol. 28 No. 1, pp. 119-125, available at: https://doi.org/10.1108/DPM-05-2018-0151

Masters, J. (2017), “Category 5 Hurricane Maria Hits Dominica”, Category 6, Weather Underground Category 6, available at: www.wunderground.com/cat6/category-5-hurricane-maria-hitsdominica (accessed February 28, 2019).

Pasch, R.J., Penny, A.B. and Berg, R. (2019), "Hurricane Maria (AL152017)", National Hurricane Center Tropical Cyclone Report, NOAA, available at: www.nhc.noaa.gov/data/tcr/AL152017_Maria.pdf (accessed February 28, 2019).

ReliefWeb (2017), "Buildings damage assessment and related density in Dominica - analysis By Parish", Imagery Analysis: September and October 2017, Published: October 18, 2017, Version 1.0, Dominica. nd, available at: https://reliefweb.int/map/dominica/buildings-damage-assessmentrelated-density-dominica-analysis-parish-imagery-analysis (accessed March 4, 2019). 